\title{
The signal transducer encoded by ampG is essential for induction of chromosomal AmpC $\beta$-lactamase in Escherichia coli by $\beta$-lactam antibiotics and 'unspecific' inducers
}

\author{
Herbert Schmidt, ${ }^{1} \dagger$ Gisela Korfmann, ${ }^{2}$ Holger Barth ${ }^{1}$ and Hans H. Martin ${ }^{1}$
}

Author for correspondence: Herbert Schmidt. Tel: +49931 2013901. Fax: +499312013445.

e-mail: hschmidt@hygiene.uni-wuerzburg.d400.de

1 Institut for Mikrobiologie, Technische Hochschule, 64287 Darmstadt, Germany

2 Bayer AG, 51368

Leverkusen, Germany

\begin{abstract}
Chemical mutagenesis of the AmpC $\beta$-lactamase-hyperinducible Escherichia coli strain SN0301/pNu305 carrying the cloned ampC and ampR genes from Citrobacter freundii 0560 gave four independent mutants in which $\beta$-lactamase was no longer inducible, or was inducible only to a low level, by $\beta$-lactam antibiotics. The genes ampC, ampR, ampD and ampE, which were essential for $\beta$-lactamase induction, were functional in these mutants. In all four mutants, the sites of mutation were mapped to $9.9 \mathrm{~min}$ on the $E$. coli chromosome. Complementation with wild-type ampG restored inducibility of $\beta$-lactamase to wild-type levels. The nucleotide sequence of all four mutant ampG alleles (ampG1, ampG3, ampG4 and ampG5) was determined. In three of the mutants, a single base exchange led to an amino acid change from glycine to aspartate at different sites in the deduced amino acid sequence. In the fourth mutant (ampG4), with low-level inducibility, the nucleotide sequence was identical to wild-type ampG. Spontaneous back-mutation of the chromosomal ampG1 mutant resulted in restoration of wild-type inducibility and a return to the wild-type ampG sequence. Unspecific induction by components of the growth medium was also dependent on intact ampG function.
\end{abstract}

Keywords: $\beta$-lactamase induction, ampG mutants, unspecific induction

\section{INTRODUCTION}

The chromosomally encoded AmpC $\beta$-lactamase is present in many Gram-negative bacteria and can be induced to high levels by $\beta$-lactam antibiotics. This is recognized as a major factor of $\beta$-lactam resistance in these organisms. Molecular studies of the induction process have revealed many properties and functions of the structural and regulatory genes involved (Normark et al., 1990, 1994). The more recently discovered gene ampG (Korfmann \& Sanders, 1989; Lindquist et al., 1993) appears to play a key role, presumably as membrane-bound transducer of the external induction signal to the intracellular $\beta$-lactamase regulon. The transducer is thought to relay the signal to

\footnotetext{
†Present address: Institut für Hygiene und Mikrobiologie, Universitat Würzburg, 97080 Würzburg, Germany.

Abbreviations: 6-Apa, 6-aminopenicillanic acid; NTG, $N$-methyl- $N^{\prime}$-nitro$\mathrm{N}$-nitrosoguanidine.

The EMBL accession numbers for the sequences reported in this paper are X82158 (ampG1), X82159 (ampG3) and X82160 (ampG5).
}

the ampR-encoded transcriptional regulator, which is thereby enabled to activate the transcription of the structural gene ampC (Honoré et al., 1989; Lindberg et al., 1985; Bartowsky \& Normark, 1993). An additional interaction with the signal or the signal-binding regulator AmpR takes place with the ampDE-encoded negative modulator, which down-regulates induction in the absence of an inducing $\beta$-lactam. In $a m p D$-defective mutants, AmpC $\beta$-lactamase is hyperinducible or semiconstitutively overproduced, causing high $\beta$-lactam resistance in these organisms (Lindberg et al., 1987; Lindquist et al., 1989b; Honoré et al., 1989).

Still unknown features of the induction process are the physical nature of the induction signal resulting from the primary interaction of the inducer with a hypothetical induction sensor, and its transmission from sensor to AmpG transducer. Different mechanisms are considered in current models. The inducing $\beta$-lactam antibiotic itself may be the AmpG-transduced and AmpR-activating signal (Normark et al., 1994). Alternatively, the signal may arise in an indirect pathway from the inactivating 
binding of the inducing $\beta$-lactam to a penicillin-binding protein acting as induction sensor. The resulting disturbance of the synthesis and morphogenesis of cell wall peptidoglycan may create an indigenous peptidoglycan metabolite functioning as 'autoinducer' (Lindberg et al., 1988; Normark et al., 1990; Tuomanen et al., 1991; Lindquist et al., 1993; Tölg et al., 1993). Thus, additional induction-specific gene functions may be involved and may be found by screening for mutation to noninducibility in the presence of the functional genes $a m p C$ and $a m p R$.

A search for such mutants described in the present paper showed that independently obtained, non-inducible mutants of Eschericbia coli containing cloned amp R and ampC of Citrobacter freundii were all defective in ampG. On the other hand, and as indication of an indirect induction pathway, we also observed that intact ampG function is essential not only for induction of $\beta$-lactamase by $\beta$ lactams but also for so-called 'unspecific' induction by components of the growth medium (Gootz \& Sanders, 1983; Cullmann et al., 1984).

\section{METHODS}

Bacterial strains and plasmids. E. coli SN0301 is an ampD1 mutant of SN03 (Lindberg et al., 1987; Lindquist et al., 1989a). E. coli strains SN0301-1, SN0301-3, SN0301-4 and SN0301-5 are $\beta$-lactam-sensitive and $\beta$-lactamase non-inducible mutants of SN0301 and are described in this study. Strains SN0301-11, SN0301-13, SN0301-14 and SN0301-15 are $\operatorname{rec} A$-positive derivatives of the mutants described above. HfrH, HfrC (Miller, 1972) and Hfr KL16 S1 (srl:: $\left.\operatorname{Tn} 10 ; \operatorname{rec} A^{+}\right)$were used for mating experiments. The latter strain was derived from Hfr KL16 by mating with JC10240 ( $\mathrm{srl}: \mathrm{:} \operatorname{Tn} 10$; rec A50) (Hantke, 1982). $\chi^{573}$, KL723 and E5014 carry the the F-primes F254, F104 and F128
(Low, 1972), respectively (provided by B. Bachmann, Genetic Stock Center, Yale University, New Haven, CT, USA). H1785 (fec A:: $\operatorname{Tn} 1732$ ), H1445 (tsx), H1469 (tsx; lon: : Tn10), KB423 $(t s x)$ and PCO135 (purE) were kindly provided by K. Hantke, Tübingen, Germany.

The recombinant plasmids used in this study are described in Table 1. Plasmids pUC19 (Vieira \& Messing, 1982), pK18 (Pridmore, 1987) and pACYC184 (Chang \& Cohen, 1978) were used as cloning vectors.

Growth media. E. coli mutants were routinely cultivated in Lbroth with addition of $2 \mathrm{~g}$ glucose $\mathrm{l}^{-1}$ and $1 \mathrm{mg}$ thiamin $\mathrm{l}^{-1}$ (Lindberg et al., 1987), and M9CA medium (Lindberg et al., 1987) supplemented with $2 \mathrm{~g}$ Casamino acids (Difco) $1^{-1}, 50 \mathrm{mg}$ uracil $\mathrm{l}^{-1}, 50 \mathrm{mg}$ tryptophan $\mathrm{l}^{-1}$ and $1 \mathrm{mg}$ thiamin $\mathrm{l}^{-1}$. Complex media and medium components for unspecific $\beta$-lactamase induction were Penassay Broth (Difco), Schaedler Anaerobic Broth (Oxoid), Peptone Soya and Peptone Special (Oxoid/ Unipath).

Chemical mutagenesis with $N$-methyl- $\boldsymbol{N}^{\prime}$-nitro- $\boldsymbol{N}$-nitrosoguanidine (NTG). Chemical mutagenesis was performed according to Adelberg et al. (1965) with slight modifications. Briefly, L-broth was inoculated with an overnight culture of $E$. coli SN0301/pNU305 to a density of $10^{6}$ cells $\mathrm{ml}^{-1}$. The culture was agitated at $37^{\circ} \mathrm{C}$ for $2.5 \mathrm{~h}$. After washing the cells three times in TM buffer $(0.05 \mathrm{M}$ Tris base, $0.05 \mathrm{M}$ maleic acid; $\mathrm{pH} 6.0$ ), $4.5 \mathrm{ml}$ of the bacterial suspension was mixed with NTG solution to give a final NTG concentration of $200 \mu \mathrm{g} \mathrm{ml}^{-1}$. After $7 \mathrm{~min}$ incubation at $37^{\circ} \mathrm{C}$ on a slow rotary shaker the cells were rapidly separated from NTG by filtering the suspension through a $0.45 \mu \mathrm{m}$ membrane filter (Sartorius). The filter was washed twice in TM buffer; the cells were carefully suspended in Lbroth and finally incubated for $2 \mathrm{~h}$ at $37^{\circ} \mathrm{C}$.

Gene mapping. For rough mapping the non-inducible mutants were made $\operatorname{rec} A^{+}$by curing them of $\mathrm{pNU} 305\left(\operatorname{amp\mathrm {R}^{+}} a m p C^{+}\right)$, transforming them with pNU344 $\left(a m p R^{+} a m p C^{+}\right)$and mating them with $E$. coli $\mathrm{Hfr} \mathrm{KL} 16\left(\operatorname{rec} A^{+} ; \operatorname{srl}:: \operatorname{Tn} 10\right)$. Conjugative

Table 1. Characteristics of recombinant plasmids used in this study

\begin{tabular}{|c|c|c|c|c|}
\hline $\begin{array}{l}\text { Recombinant } \\
\text { plasmid }\end{array}$ & Vector & Relevant genotype/origin of inserted DNA & Marker* & Reference \\
\hline pNU305 & pBR322 & $\begin{array}{l}\text { Wild-type } a m p \mathrm{R} \text { and } a m p C \text { genes from } \\
\text { C. freundii OS } 60\end{array}$ & $\mathrm{Tc}^{\mathrm{r}}$ & Lindberg et al. (1985) \\
\hline pNU344 & $\mathrm{pACYC184}$ & $\begin{array}{l}\text { Wild-type } a m p R \text { and } a m p C \text { genes from } \\
\text { C. freundii OS60 }\end{array}$ & $\mathrm{Cm}^{\mathrm{r}}$ & Lindberg et al. (1987) \\
\hline pNU413 & pACYC184 & $\begin{array}{l}\text { Wild-type } a m p D \text { and } a m p E \text { genes from } \\
\text { E. coli SN03 }\end{array}$ & $\mathrm{Cm}^{\mathrm{r}}$ & Lindquist et al. (1989a) \\
\hline pGKS273-3 & pACYC184 & Wild-type ampG gene from E. coli JRG582 & $\mathrm{Cm}^{\mathrm{r}}$ & G. Korfmann, unpublished \\
\hline pMH203 & pACYC184 & ampG1 mutant allele from E. coli SN0301-1 & $\mathrm{Cm}^{\mathrm{r}}$ & This study \\
\hline pMH203-3 & pUC19 & ampG1 mutant allele subcloned from $\mathrm{pMH} 203$ & $A p^{r}$ & This study \\
\hline PMH303-1 & pUC19 & ampG3 mutant allele from E. coli SN0301-3 & $A p^{r}$ & This study \\
\hline pMH305-1 & pUC19 & ampG5 mutant allele from E. coli $\mathrm{SN} 0301-5$ & $A p^{r}$ & This study \\
\hline pMH600 & pK18 & Wild-type ampG gene subcloned from pGKS273-3 & $\mathrm{Km}^{\mathrm{r}}$ & This study \\
\hline pMH601 & $\mathrm{pK} 18$ & ampG1 mutant allele cloned from $\mathrm{pMH} 203-3$ & $\mathrm{Km}^{\mathrm{r}}$ & This study \\
\hline pMH603 & $\mathrm{pK} 18$ & ampG3 mutant allele cloned from pMH303-1 & $\mathrm{Km}^{\mathrm{r}}$ & This study \\
\hline PMH605 & $\mathrm{pK} 18$ & ampG5 mutant allele cloned from pMH305-1 & $\mathrm{Km}^{\mathrm{r}}$ & This study \\
\hline pMH601-R1 & $\mathrm{pK} 18$ & $\begin{array}{l}\text { Wild-type ampG; back-mutation of } a m p G 1 \\
\text { (pMH601) }\end{array}$ & $\mathrm{Km}^{\mathrm{r}}$ & This study \\
\hline
\end{tabular}

* Resistance to the respective antibiotic: Tc, tetracycline; $\mathrm{Cm}$, chloramphenicol; Ap, ampicillin; Km, kanamycin. 
mating in liquid culture was performed as described by Miller (1972), with a ratio of donor to recipient of $1: 5$. Tetracyclineresistant transconjugants were selected and tested for the presence of the $\operatorname{rec} A$ gene by the method of Clark \& Margulies (1965). Complementation of gene defects was tested by mating with F-primes (Low, 1972; Miller, 1972). Transconjugants which were able to complement the gene defects were selected on agar plates containing $256 \mu \mathrm{g}$ ampicillin $\mathrm{ml}^{-1}$.

Fine-structure mapping was performed by cotransduction experiments with bacteriophage $\mathrm{P} 1_{\mathrm{vir}}$ as described by Miller (1972). To determine the relative position of the mutation in relation to the marker genes, three-point analysis was performed. The distance between the cotransduced markers was calculated from the equation of $\mathrm{Wu}(1966): f=(1-X / L)$, with $L=2 \cdot 0$.

Polymerase chain reaction (PCR). Amplification of the mutant alleles was performed in a total volume of $50 \mu \mathrm{l}$ containing $1 \mathrm{ng}$ chromosomal DNA of the mutants, each deoxynucleoside triphosphate at $200 \mu \mathrm{M}, 50 \mathrm{pmol}$ of primers HS1 (5'-CCCGAATTCTGCCTCCTGGCCC-3') and HS2 (5'-CCCAAGCTTCGTAATAATTACGGCG-3' $\left.{ }^{\prime}\right), 5 \mu \mathrm{l}$ tenfold-concentrated Taq DNA polymerase synthesis buffer and $2.5 \mathrm{U}$ Taq DNA polymerase (Perkin-Elmer Cetus). DNA was denatured at $94^{\circ} \mathrm{C}$ for $60 \mathrm{~s}$, the primers were annealed at $50^{\circ} \mathrm{C}$ for $60 \mathrm{~s}$ and primer extension was conducted for $90 \mathrm{~s}$ at $72{ }^{\circ} \mathrm{C}$. Thermal cycling was carried out in a Perkin-Elmer Cetus thermal cycler N801-0177. After 30 cycles the amplification products were subjected to a final extension step of $5 \mathrm{~min}$ at $72^{\circ} \mathrm{C}$.

Recombinant DNA methods. Standard procedures were used (Sambrook et al., 1989).

Nucleotide sequence analysis. DNA sequencing was performed by the method of Sanger et al. (1977) with the T7 sequencing kit (Pharmacia LKB), following the manufacturer's instructions. Labelling was performed with $\left[{ }^{35} \mathrm{~S}\right] \mathrm{dATP} \alpha \mathrm{S}$ (approx. $1 \mathrm{Ci} \mathrm{mmol}^{-1} ; 37 \mathrm{GBq} \mathrm{mmol}^{-1}$ ). Target DNA, cloned in $\mathrm{PUC}$ vectors, was used for the double-strand sequencing procedure. Sequencing products were separated on field gradient gels as described by Ansorge \& Barker (1984) and visualized on X-ray film (Kodak XAR5) after exposure for $24 \mathrm{~h}$.

$\boldsymbol{\beta}$-Lactamase techniques. Procedures described by Lindberg et al. $(1985,1987)$ and Tölg et al. (1993) were used. Induction of $\beta$-lactamase was performed with 6-aminopenicillanic acid (6-Apa, $250 \mathrm{mg} \mathrm{ml}^{-1}$ ). $\beta$-Lactamase activity was measured with the substrate cephalexin $(200 \mu \mathrm{M})$. One unit of $\beta$-lactamase hydrolyses $1 \mu \mathrm{mol}$ substrate $\mathrm{min}^{-1}$. Total protein was determined as described by Bradford (1976).

\section{RESULTS}

\section{Generation of $\beta$-lactamase non-inducible mutants in E. coli carrying cloned genes ampR and ampC}

Mutagenesis with NTG was performed on the ampDdefective, $\beta$-lactamase-hyperinducible $E$. coli SN0301 (Lindquist et al., 1989a) carrying cloned genes ampR and ampC from $C$. freundii OS60 on plasmid pNU305 (Lindberg et al., 1985). Rare, non-inducible mutants were obtained only after heavy mutagenesis with $200 \mu \mathrm{g}$ NTG $\mathrm{ml}^{-1}$, leaving 5-10\% surviving bacteria. The presence of the multicopy plasmid pNU305 during mutagenesis enhanced the recovery of desired mutants whilst keeping the risk of isolating non-inducible $a m p R$ - or $a m p C$ defective mutants low. The parent strain SN0301/ pNU305 was resistant to $1024 \mu \mathrm{g}$ ampicillin $\mathrm{ml}^{-1}$. Among the surviving mutagenized bacteria, ampicillin-sensitive and presumably non-inducible mutants were detected at a frequency of $3 \times 10^{-5}$ by their inability to grow on replica plates containing $256 \mu \mathrm{g}$ ampicillin $\mathrm{ml}^{-1}$. Four independent, ampicillin-sensitive mutants were obtained. $\beta$-Lactamase was completely non-inducible in three of these mutants: SN0301-1, SN0301-3 and SN0301-5. In mutant SN0301-4 the enzyme was inducible to a low level. Values of $\beta$-lactamase activity and $\beta$-lactam sensitivity are shown in Table 2. Plasmid pNU305, purified from each of the mutants, did not transfer the non-inducibility when transformed into the parent strain SN0301. Nor was inducibility restored when the mutants were cured of resident plasmid pNU305 and retransformed with pNU305 isolated from the inducible strain SN0301/ pNU305. Also, the mutants remained non-inducible after transformation with pNU413 (Lindquist et al., 1989a). Therefore, genes $a m p R, a m p C$, $a m p D$ and $a m p E$ were not involved in the loss of inducibility.

\section{Localization of the mutation site at $9.9 \mathrm{~min}$ on the E. coli chromosome}

Matings of $\operatorname{rec} A^{+}$derivatives of the non-inducible mutants with different $\mathrm{Hfr}$ strains and with $\mathrm{F}$-primes yielded recombinants inducible for $\beta$-lactamase and resistant to ampicillin only with $\mathrm{HfrH}$ and $\mathrm{HfrC}$ [the origin of transfer (oriT) sites of these donors are at 99 and $12 \mathrm{~min}$, respectively] and with prime F254 (lac-lip, 8-15 min region of the $E$. coli chromosome). Cotransduction mapping was performed with $\mathrm{P} 1_{\mathrm{vir}}$ lysates of $E$. coli strains with the selectable markers fec $A:: \operatorname{Tn} 1732\left(\mathrm{Km}^{\mathrm{r}}\right)$, tsx, lon and purE at 7,9,10 and $12 \mathrm{~min}$, respectively. Frequencies of cotransduction of ampicillin resistance and calculated map distances were $52 \%$ and 0.41 min with $t s x$, and $83 \%$ and $0.12 \mathrm{~min}$ with lon. No cotransduction with the flanking genes $f e c A$ and purE was observed. The sequential order of the mutation site in relation to the closest markers $t 5 x$ and lon was established by monitoring cotransduction of the three markers into mutant strain SN0301-1/pNU305 by a P1 ${ }_{\text {vir }}$ lysate of E. coli $\mathrm{H} 1469$ ( $t s x$ lon). Among the transductants, strains with simultaneous resistance to ampicillin and phage T6 but devoid of lon were obtained. This excluded a position of lon between the site of mutation to non-inducibility and the $t s x$ gene. Based on a distance of $0.58 \mathrm{~min}$ between $t 5 x$ and lon, calculated from $35 \%$ cotransduction frequency, the site of mutation to non-inducibility in all four mutant strains, including the weakly inducible SN0301-4/pNU305, was identically localized at $9.9 \mathrm{~min}$ on the E. coli map, close to lon.

\section{Complementation of non-inducibility and $\beta$-lactam sensitivity of the mutants by the cloned ampG gene from $E$. coll}

Recently, Lindquist et al. (1993) have mapped the new gene amp $G$ to $9.6 \mathrm{~min}$ on the chromosomal map of $E$. coli by hybridization of the cloned wild-type ampG with the relevant phages from the Kohara lambda library (Kohara et al., 1987), and by comparison of restriction maps 
Table 2. Non-inducibility of $\beta$-lactamase and $\beta$-lactam sensitivity in NTG-generated mutants of $E$. coli SN0301/pNU305 (ampR $R^{+} a m p C^{+}$), and restoration of inducibility and $\beta$-lactam resistance by transformation of mutants with pGKS273-3 (ampG+)

$\beta$-Lactamase was induced with 6-Apa. Values of specific enzyme activities are means of triplicate measurements.

\begin{tabular}{|c|c|c|c|c|}
\hline \multirow[t]{3}{*}{ Strain } & \multirow{2}{*}{\multicolumn{2}{|c|}{$\begin{array}{c}\beta \text {-Lactamase } \\
\text { specific activity } \\
{\left[U{\left.\text { (mg protein })^{-1}\right]}^{-1}\right.}\end{array}$}} & \multicolumn{2}{|c|}{$\operatorname{MIC}\left(\mu \mathrm{g} \mathrm{ml}^{-1}\right)$} \\
\hline & & & \multirow[t]{2}{*}{ Ampicillin } & \multirow[t]{2}{*}{ Cefotaxime } \\
\hline & $\begin{array}{c}\text { Non- } \\
\text { induced }\end{array}$ & Induced & & \\
\hline SN0301/pNU305 & 0.8 & 15 & 2048 & 64 \\
\hline SN0301-1/pNU305 & 0.5 & 0.5 & 32 & 4 \\
\hline SN0301-1/pNU305 + pGKS273-3 & 0.6 & 12 & 2048 & 64 \\
\hline SN0301-3/pNU305 & $0 \cdot 35$ & $0 \cdot 3$ & 32 & 4 \\
\hline SN0301-3/pNU305 + pGKS273-3 & 0.5 & 15 & 2048 & 64 \\
\hline SN0301-4/pNU305 & 0.5 & 5 & 64 & 8 \\
\hline SN0301-4/pNU305 + pGKS273-3 & 0.7 & 12 & 2048 & 64 \\
\hline SN0301-5/pNU305 & $0 \cdot 3$ & 0.3 & 32 & 4 \\
\hline SN0301-5/pNU305 + pGKS273-3 & 0.75 & 15 & 2048 & 64 \\
\hline
\end{tabular}
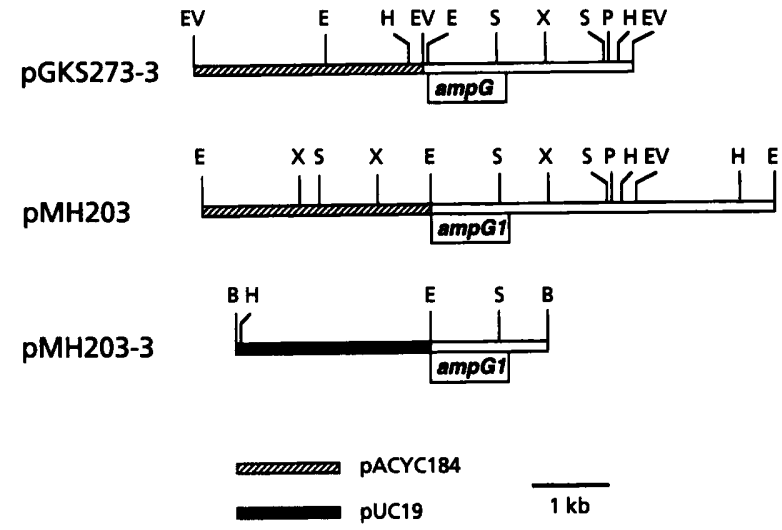

Fig. 1. Restriction maps of recombinant ampG plasmids pGKS273-3 $\left(a m p G^{+}\right.$), pMH203 (ampG1) and pMH203-3 (ampG1). The restriction sites for EcoRI (E), Xholl (X), Sall (S), Pstl (P), HindIII (H), ECORV (EV) and BamHI (B) are indicated.

indicating the immediate neighbourhood of $a m p G$ to the flanking genes cyo $A$ and bol $A$ (Lindquist et al., 1993; Aldea et al., 1988, 1989; Chepuri et al., 1990). It was first shown by Korfmann \& Sanders (1989) that cloned ampG restores the inducible synthesis of $\beta$-lactamase in a noninducible mutant of Enterobacter cloacae in the presence of wild-type $a m p C$ and $a m p R$.

The non-inducible E. coli mutants SN0301-1, -3, -4 and -5 , each containing pNU305, were tested for possible defects in amp $G$ by additional transformation with pGKS273-3, carrying wild-type ampG from $E$. coli JRG582 cloned into the EcoRV site of pACYC184 (Fig. 1). All four mutants were equally complemented by ampG to inducibility of $\beta$-lactamase and resistance to cefotaxime and ampicillin, and were indistinguishable from parent strain SN0301 (Table 2). Thus, all mutants were defective in $a m p G$.

\section{Cloning of the ampG alleles from the non-inducible mutants}

Chromosomal EcoRI fragments of ampG1 mutant strain SN0301-1 were isolated and ligated into pACY184 linearized with EcoRI. Screening of 250 clones from this genomic library by hybridization with a pGKS273-3derived EcoRI-SalI fragment carrying part of ampG revealed a single probe-positive recombinant plasmid. This plasmid carried a $5.3 \mathrm{~kb}$ chromosomal EcoRI fragment and was termed pMH203 (Fig. 1). Comparison of the restriction patterns of pGKS273-3 and pMH203 confirmed that the cloned $5.3 \mathrm{~kb}$ fragment of pMH203 contained the mutant allele ampG1 (Fig. 1). Subcloning of the ampG1 allele by ligating the $1.9 \mathrm{~kb}$ EcoRI-XboII fragment from pMH203 into pUC19, which was linearized with EcoRI and BamHI, yielded plasmid pMH 203-3 (Fig. 1).

The ampG mutant alleles of strains SN0301-3 (ampG3), SN0301-4 (ampG4) and SN0301-5 (ampG5) were amplified by PCR using primers HS1 (containing a $5^{\prime}$ - EcoRI site and HS21 (containing a 5'- HindIII site). Amplification products with a size of $1.6 \mathrm{~kb}$ were obtained, spanning the open reading frames (ORFs) of ampG3, ampG4 and ampG5. After double restriction with EcoRI and HindIII, the respective amplification products were cloned into pUC19 and independently transformed into E. coli DH5 $\alpha$ so that four independently cloned PCR products could be analysed by DNA sequencing from each mutant allele. 


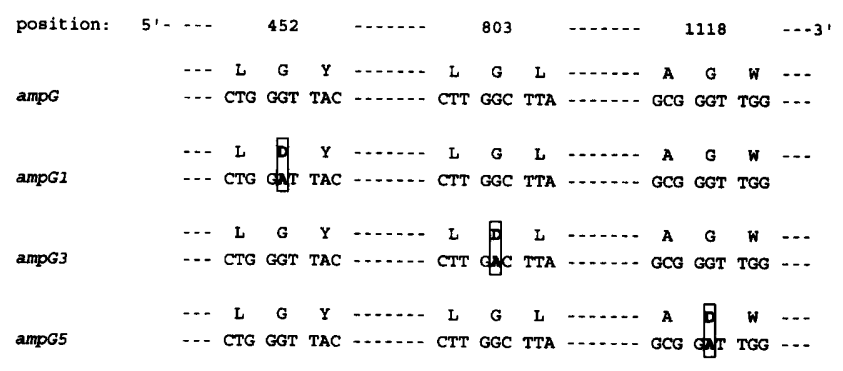

Fig. 2. Sites of point mutations in the nucleotide sequences (lower line) of different ampG mutant genes in E. coli SN0301-1 (ampG1), SN0301-3 (ampG3) and SN0301-5 (ampG5), and the respective amino acid changes (upper line) in the AmpG protein in comparison with the wild-type sequence (Lindquist et al., 1993). The positions of the nucleotide sequence exchanges (boxed) are indicated in relation to the ORF of ampG. Base substitution at positions 452,804 and 1118 led to amino acid exchanges $G^{151} \rightarrow D^{151}$ in AmpG1, $G^{268} \rightarrow D^{268}$ in AmpG3 and $G^{373} \rightarrow D^{373}$ in AmpG5, respectively.

\section{Nucleotide sequences of the ampG mutant alleles}

The 1.9 and $1.6 \mathrm{kbp}$ inserts of the recombinant pUC plasmids carrying the amp $G$ mutant alleles were sequenced by the dideoxy chain-termination method, using synthetic oligonucleotides as internal primers. From each of the genes ampG3, ampG4 and ampG5 at least two of the independent clones were sequenced, in order to identify any differences resulting from DNA copy errors caused by the Taq DNA polymerase. However, none were discovered.

DNA sequence analysis of the mutant ampG alleles derived from SN0301-1, SN0301-3 and SN0301-5 revealed single base changes at positions 452 (ampG1), 803 (ampG3) and $1118(a m p G 5)$ in the respective ORFs. In each case the base change was confirmed by sequencing the complementary second DNA strand in the mutated region. These base changes all resulted in an exchange of glycine for aspartate at different sites in the presumptive AmpG1 $\left(\mathrm{G}^{151} \rightarrow \mathrm{D}^{151}\right)$, AmpG3 $\left(\mathrm{G}^{268} \rightarrow \mathrm{D}^{268}\right)$ and AmpG5 $\left(G^{373} \rightarrow D^{373}\right)$ mutant proteins (Fig. 2). The nucleotide sequence of ampG4 was identical to that of wild-type $\operatorname{ampG.}$

\section{Dependence of inducibility of $\beta$-lactamase on the intact ampG gene}

For functional assays, the mutant $a m p G$ genes as well as wild-type amp $G$ were cloned in plasmid pK18 (Pridmore, 1987) carrying a kanamycin-resistance gene. Genes ampG1, ampG3 and ampG5 were excised from plasmids pMH203-3, pMH303-1 and pMH305-1 with EcoRI and HindIII and ligated into $\mathrm{pK} 18$. Similarly, wild-type ampG was excised from pGKS273-3 with EcoRI and XhoII, and ligated into pK18. The resulting plasmids were pMH600 $\left(a m p G^{+}\right)$, pMH601 (ampG1), pMH603 (ampG3) and pMH605 (ampG5).

$\beta$-Lactam resistance and inducibility of $\beta$-lactamase were tested after transforming these plasmids in the non-
Table 3. Functional assay of $E$. coli wild-type (in pMH600) and mutant alleles (in pMH601, pMH603, pMH604 and pMH605) of the ampG gene cloned in pK18 and transformed into ampG-defective $E$. coli SN0301-1/pNU344 (ampR ampC')

Restoration of $a m p G$ function by spontaneous back-mutation in pMH601-R1 is also shown. For expression of ampG product and $\beta$-lactamase, transformants were induced with IPTG and 6-Apa. Values of specific activities of $\beta$-lactamase are means of triplicate measurements.

\begin{tabular}{|c|c|c|c|c|}
\hline \multirow[t]{2}{*}{ Plasmid } & \multirow[t]{2}{*}{$a m p G$} & \multicolumn{2}{|c|}{$\begin{array}{c}\boldsymbol{\beta} \text {-Lactamase } \\
\text { specific } \\
\text { activity } \\
{\left[\mathrm{U}\left(\mathrm{mg}^{\mathrm{m}} \text { protein }\right)^{-1}\right]}\end{array}$} & \multirow[t]{2}{*}{$\begin{array}{c}\text { MIC of } \\
\text { cefotaxime } \\
\left(\mu \mathrm{gl}^{-1}\right)\end{array}$} \\
\hline & & $\begin{array}{c}\text { Non- } \\
\text { induced }\end{array}$ & Induced & \\
\hline pMH600 & $a m p G^{+}$ & 0.8 & 13 & 64 \\
\hline pMH601 & $a m p G 1$ & $0 \cdot 2$ & $0 \cdot 15$ & 2 \\
\hline pMH603 & $a m p G 3$ & $0 \cdot 15$ & 0.5 & 8 \\
\hline pMH605 & $a m p G 5$ & $0 \cdot 15$ & $0 \cdot 15$ & 2 \\
\hline pMH601-R1 & $a m p G^{+}$ & 5 & $13 \cdot 5$ & 128 \\
\hline pK18 & - & $0 \cdot 3$ & $0 \cdot 25$ & 2 \\
\hline
\end{tabular}

inducible E. coli mutant SN0301-1/pNU344 (Table 3). Upon induction of the expression of the ampG gene product and $\beta$-lactamase with IPTG and 6-Apa, transformants were resistant to cefotaxime and inducible for $\beta$-lactamase in the presence of wild-type ampG, but not with ampG1 and ampG5. Slight leakiness of mutant ampG3 was recognizable in transformants with pMH603 by a moderately elevated inducibility of $\beta$-lactamase and lower cefotaxime sensitivity. Nevertheless, it was evident that the loss of inducibility was the result of each of the identified point mutations.

\section{Restoration of inducibility of $\beta$-lactamase by back- mutation of ampG1 to wild-type}

Back-mutation of chromosomal E. coli mutant ampG to wild-type with concomitant restoration of inducibility has been reported (Lindquist et al., 1993). A search for spontaneous back-mutation of a cloned mutant allele to the wild-type am $\not G$ phenotype was carried out in plasmid pMH601 (ampG1). Individuals demonstrating $\beta$-lactam resistance, presumably due to regained inducibility of $\beta$ lactamase, were selected from $E$. coli transformants SN0301-1/pNU344 + pMH601 by their ability to grow on LB-agar plates containing cefotaxime $\left(16 \mu \mathrm{g} \mathrm{ml}^{-1}\right)$, IPTG, chloramphenicol and kanamycin. From $2.6 \times 10^{10}$ plated transformants, 29 cefotaxime-resistant colonies were obtained. In order to distinguish back-mutations of $a m p G 1$ in pMH601 from those in chromosomal ampG1 in the host bacterium SN0301-1, plasmid pMH601 was purified from all cefotaxime-resistant isolates and again tested for the ability to mediate cefotaxime resistance after retransformation into SN0301-1/pNU344. Five indepen- 
Table 4. ampG-dependent stimulation by complex growth media of the expression of $\beta$-lactamase from cloned ampR, ampC of $C$. freundii on pNU344 in E. coli

Specific $\beta$-lactamase activity was determined in strains grown to late exponential phase in supplemented M9 medium (M9+), Penassay Broth (PB) or Schaedler Anaerobic Broth (SAB). Values are means of triplicate measurements.

\begin{tabular}{|c|c|c|c|c|}
\hline \multirow[t]{2}{*}{ Strain } & \multirow[t]{2}{*}{ ampG allele } & \multicolumn{3}{|c|}{$\begin{array}{c}\beta \text {-Lactamase } \\
\text { specific activity } \\
{\left[\mathrm{U}(\mathrm{mg} \text { protein })^{-1}\right]} \\
\text { after growth in: }\end{array}$} \\
\hline & & $\mathbf{M 9}^{+}$ & PB & SAB \\
\hline SN0301/pNU305 & $a m p G^{+}$ & $2 \cdot 1$ & $2 \cdot 1$ & $9 \cdot 2$ \\
\hline SN0301-1/pNU305 & $a m p G 1$ & $0 \cdot 13$ & $0 \cdot 16$ & $0 \cdot 12$ \\
\hline $\begin{array}{l}\text { SN0301-1/pNU305+ } \\
\text { pGKS273-3 }\end{array}$ & $a m p G 1+a m p G^{+}$ & $0 \cdot 49$ & 0.53 & $1 \cdot 8$ \\
\hline
\end{tabular}

dent plasmid-borne back-mutants were identified, which were termed pMH601-R1 to -R5. Surprisingly, and for reasons so far unknown, constitutive expression of $\beta$ lactamase in the presence of all revertant plasmids R1-R5 was much higher than in the control with ampG wildtype plasmid pMH600. Typical values for inducibility of $\beta$-lactamase and $\beta$-lactam resistance are shown for transformants containing pMH601-R1 in Table 3. Nucleotide sequencing of pMH601-R1 revealed the exchange of $\mathrm{dA}$ for $\mathrm{dG}$ at position 452 of the ORF of mutant gene ampG1 and thus return to the wild-type amp $G$ sequence.

\section{Unspecific, ampG-dependent induction of AmpC $\beta$ - lactamase by components of the growth medium}

Elevated expression of chromosomal $\beta$-lactamase during growth in certain complex growth media has been described in Ent. cloacae (Gootz \& Sanders, 1983), and highly effective 'unspecific induction' of this enzyme by Schaedler Anaerobic Broth (SAB) has been observed (Cullmann et al., 1984). In E. coli SN0301 $\left(a m p G^{+}\right) /$ pNU305 we confirmed this stimulating activity of $\mathrm{SAB}$, in contrast to Penassay Broth and $\mathrm{M}^{+}$medium supplemented with complex additives (Table 4). Moreover, the unspecific induction by $\mathrm{SAB}$ was ampG-dependent. In E. coli SN0301-1 (ampG1)/pNU305, expression of $\beta$-lactamase was much decreased and equally low in all growth media. Transformation of pGKS273-3 (amp $G^{+}$) into SN0301-1 (ampG1)/pNU305 led to elevated $\beta$-lactamase expression but only to partial restoration of inducibility by SAB.

Preliminary screening for unspecific inducing factors was undertaken by determining the $\beta$-lactamase activity in $E$. coli SN0301/pNU305 grown in Penassay Broth with individual addition of the components of $\mathrm{SAB}$ at concentrations as described by the manufacturer. Haemin, cysteine hydrochloride and Tris base were without effect. However, with added Peptone Soya $\left(15 \mathrm{~g} \mathrm{l}^{-1}\right)$ and Pep- tone Special $\left(5 \mathrm{~g} \mathrm{l}^{-1}\right)$ specific enzyme activities were $9.9 \mathrm{U}$ and $12 \cdot 2 \mathrm{U}$ (mg protein $)^{-1}$, respectively.

\section{DISCUSSION}

The search for mutants with non-inducibility of AmpC $\beta$ lactamase yielded only mutants defective in ampG and provided no evidence of new genes involved in this process in addition to those already known. Presumably, therefore, the complete list of genes engaged in the expression and regulation of AmpC $\beta$-lactamase comprises $a m p C, a m p R$, ampD, ampE and $a m p G$, whose product probably fulfils the key function of transducer of the external induction signal. Several observations indicate that the AmpG-interacting induction signal may be a metabolite of bacterial cell wall peptidoglycan and may exert its function by interfering in different ways with the synthesis of this polymer. Induction of $\mathrm{AmpC} \beta$-lactamase in $E$. coli by $\beta$-lactam compounds has been shown to depend on the function of the product of the cell-division gene $f t s Z$ (Ottolenghi \& Ayala, 1991) and the cell-shapedetermining penicillin-binding protein 2 (Oliva et al., 1989).

$\beta$-Lactamase induction was also found to occur in E. coli SN0301/pNU305 $\left(a m p \mathrm{R}^{+} a m p C^{+}\right)$during the mechanistically quite different inhibition of peptidoglycan synthesis by glycine and D-methionine. Absence of the glycine/D-methionine-mediated induction in the ampGdefective mutant SN0301-1/pNU305 suggests the essential function of a peptidoglycan-derived and AmpGinteracting signal in this process also (Martin \& Schmidt, 1993). In the presence of all required amp genes, AmpC $\beta$-lactamase was expressed constitutively but was not inducible in cell wall-less L-form protoplasts (Tölg et al., 1993).

The observed 'unspecific' but also ampG-dependent induction of $\beta$-lactamase by specific peptones in complex growth medium may be due to so far unknown components with modulating and signal-producing activity on peptidoglycan synthesis. Alternatively, signal production may be the result of a general shift-up in polymer synthesis and recycling during growth in the respective rich medium.

The amp $G$ gene has been shown to lack its own promoter. Instead, it is cotranscribed as part of an operon together with a 579 bp upstream ORF of still unknown function (Lindquist et al., 1993). Lindquist et al. (1993) have demonstrated a polar effect on $a m p G$ function by insertion mutagenesis in the upstream ORF. Consequently, the partial defect in ampG function in strain SN0301-4 could be due to mutation in the operon region upstream of ampG.

In the mutants SN0301-1, SN0301-3 and SN0301-5 described in this study the inactivation of $a m p G$ function is caused by single point mutations at widely separated positions within the gene. Obviously, the central function of AmpG depends on the correct amino acid sequence in the major part of the signal-transducer protein. It should therefore also be highly sensitive to the action of inhibitors 
at different positions in the molecule. Treatment with $\beta$ lactams in combination with antibiotic action directed at AmpG could be expected to overcome bacterial resistance due to- $\beta$-lactamase induction. It should also eliminate the hyperinducibility or semi-constitutive overproduction of Amp $\beta$-lactamase due to mutational defect in ampD, which is a major cause of high resistance to extendedspectrum $\beta$-lactam antibiotics in Gram-negative bacteria (Lindberg \& Normark, 1987; Lindquist et al., 1989b).

\section{ACKNOWLEDGEMENTS}

We gratefully thank Susanne Lindquist, Umeå, and Staffan Normark, Stockholm, for good cooperation and helpful discussions. Herbert Schmidt thanks K. Hantke, Tübingen, for providing strains and advice on gene mapping, and G. Sawers and A. Böck, München, for PCR facilities. He also thanks Helge Karch and Jürgen Heesemann, Würzburg, for support of this work.

This work was supported by the Deutsche Forschungsgemeinschaft and the Fonds der Chemischen Industrie.

\section{REFERENCES}

Adelberg, E. A., Mandel, M. \& Chen, G. (1965). Optimal conditions for mutagenesis by $N$-methyl- $N^{\prime}$-nitro- $N$-nitrosoguanidine in Eschericbia coli K12. Biochem Biopbys Res Commun 18, 788-795.

Aldea, M., Hernandez-Chico, C., De la Campa, A. G., Kushner, S. R. \& Vicente, M. (1988). Identification, cloning, and expression of bol $A$, an ftsZ-dependent morphogene of Escherichia coli. J Bacteriol 170, 5169-5176.

Aldea, M., Garrido, T., Hernandez-Chico, C., Vicente, M. \& Kushner, S. R (1989). Induction of a growth-phase-dependent promoter triggers transcription of bol $A$, an Escherichia coli morphogene. EMBO J 8, 3923-3931.

Ansorge, W. \& Barker, R. (1984). System for DNA sequencing with resolution up to 600 base pairs. J Biochem Biophys Meth 9, 33-47.

Bartowsky, E. \& Normark, S. (1993). Interactions of wild-type and mutant AmpR of Citrobacter freundii with target DNA. Mol Microbiol 10, 555-565.

Bradford, M. M. (1976). A rapid and sensitive method for the quantitation of microgram quantities of protein utilizing the principle of protein-dye binding. Anal Biochem 72, 248-254.

Chang, A. C. Y. \& Cohen, S. N. (1978). Construction and characterization of amplifiable multicopy DNA cloning vehicles derived from the P15A cryptic miniplasmid. J Bacteriol 134, 1141-1156.

Chepuri, V., Lemieux, L., Au, D. C.-T. \& Gennis, R. B. (1990). The sequence of the cyo operon indicates substantial structural similarities between the cytochrome $o$ ubiquinol oxidase of Eschericbia coli and the $a a_{3}$-type family of cytochrome $c$ oxidases. $J$ Biol Chem 265, 11185-11192.

Clark, A. \& Margulies, A. D. (1965). Isolation and characterization of recombination-deficient mutants of Eschericbia coli K-12. Proc Natl Acad Sci US A 53, 451-459.

Cullmann, W., Dalhoff, A. \& Dick, W. (1984). Nonspecific induction of $\beta$-lactamase in Enterobacter cloacae. J Gen Microbiol 130, 1781-1786.

Gootz, T. D. \& Sanders, C. C. (1983). Characterization of betalactamase induction in Enterobacter cloacae. Antimicrob Agents Chemother 23, 91-97.

Hantke, K. (1982). Negative control of iron uptake systems in Escherichia coli K-12. FEMS Microbiol Lett 15, 83-86.
Honoré, N., Nicolas, M. H. \& Cole, S. (1989). Regulation of enterobacterial cephalosporinase production: the role of a membrane-bound sensory transducer. Mol Microbiol 3, 1121-1130.

Kohara, Y., Akiyama, K. \& Isono, K. (1987). The physical map of the whole $E$. coli chromosome: application of a new strategy for rapid analysis and sorting of a large genomic library. Cell 50, 495-508.

Korfmann, G. \& Sanders, C. C. (1989). ampG is essential for highlevel expression of AmpC $\beta$-lactamase in Enterobacter cloacae. Antimicrob Agents Chemother 33, 1946-1951.

Lindberg, F. \& Normark, S. (1987). Common mechanism of ampC beta-lactamase induction in enterobacteria : regulation of the cloned Enterobacter cloacae P99 beta-lactamase gene. J Bacteriol 169, 758-763.

Lindberg, F., Westman, L. \& Normark, S. (1985). Regulatory components in $C$ itrobacter freundii ampC $\beta$-lactamase induction. Proc Natl Acad Sci US A 82, 4620-4624.

Lindberg, F., Lindquist, S. \& Normark, S. (1987). Inactivation of the $a m p D$ gene causes semiconstitutive overproduction of the inducible Citrobacter freundii beta-lactamase. J Bacteriol 169, 1923-1928.

Lindberg, F., Lindquist, S. \& Normark, S. (1988). Genetic basis of overproduction of chromosomal class I $\beta$-lactamase in nonfastidious Gram-negative bacilli. Rev Infect Dis 10, 782-785.

Lindquist, S., Galleni, M., Lindberg, F. \& Normark, S. (1989a). Signalling proteins in enterobacterial AmpC beta-lactamase regulation. Mol Microbiol 3, 1091-1102.

Lindquist, S., Lindberg, F. \& Normark, S. (1989b). Binding of the Citrobacter freundii AmpR regulator to a single DNA site provides both autoregulation and activation of the inducible ampC betalactamase gene. J Bacteriol 171, 3746-3753.

Lindquist, S., Weston Hafer, K., Schmidt, H., Piel, C., Korfmann, G., Erickson, J., Sanders, C., Martin, H. H. \& Normark, S. (1993). AmpG, a signal transducer in chromosomal beta-lactamase induction. Mol Microbiol 9, 703-715.

Low, K. B. (1972). Escherichia coli K-12 F-prime factors, old and new. Bacteriol Rev 36, 587-607.

Martin, H. H. \& Schmidt, H. (1993). Disturbance of peptidoglycan synthesis by glycine and D-methionine creates a signal for the ampG mediated induction of AmpC $\beta$-lactamase in Escherichia coli. In Bacterial Growth and Lysis - Metabolism and Structure of the Bacterial Sacculus, pp. 341-346. Edited by J. V. Höltje \& W. Löffelhardt. New York: Plenum.

Miller, J. H. (1972). Experiments in Molecular Genetics. Cold Spring Harbor, NY: Cold Spring Harbor Laboratory.

Normark, S., Bartowsky, E., Lindquist, S., Galleni, M., Tuomanen, E., Martin, H. H. \& Schmidt, H. (1990). The molecular basis of $\beta$ lactamase induction in enterobacteria. In New Antibacterial Strategies, pp. 161-173. Edited by H. C. Neu. Edinburgh: Churchill Livingstone.

Normark, S., Bartowsky, E., Erickson, J., Jacobs, C., Lindberg, F., Weston-Hafer, K. \& Wikström, M. (1994). Mechanisms of chromosomal $\beta$-lactamase induction in Gram-negative bacteria. In Bacterial Cell Wall. New Comprehensive Biochemistry, pp. 485-503. Edited by J. M. Ghuysen \& R. Hakenbeck. Amsterdam: Elsevier Science.

Oliva, B., Bennett, P. M. \& Chopra, I. (1989). Penicillin-binding protein 2 is required for induction of the Citrobacter freundii class I chromosomal beta-lactamase in Escherichia coli. Antimicrob Agents Chemother 33, 1115-1117.

Ottolenghi, A. C. \& Ayala, J. A. (1991). Induction of a class I $\beta$ lactamase from Citrobacter freundii in Escherichia coli requires active $f t s Z$ but not $f t s A$ or $f t s Q$ products. Antimicrob Agents Chemother 35, 2359-2356. 
Pridmore, R. D. (1987). New and versatile cloning vectors with kanamycin-resistance marker. Gene 56, 309-312.

Sambrook J., Fritsch, E. F. \& Maniatis, T. (1989). Molecular Cloning: a Laboratory Manual. Cold Spring Harbor, NY, Cold Spring Harbor Laboratory.

Sanger, F., Nicklen, S. \& Coulson, A. R. (1977). DNA sequencing with chain terminating inhibitors. Proc Natl Acad Sci USA 74, 5463-5467.

Tölg, M., Schmidt, H., Schierl, R., Datz, M. \& Martin, H. H. (1993). Dependence of induction of enterobacterial AmpC $\beta$-lactamase on cell-wall peptidoglycan, as demonstrated in Proteus mirabilis and its wall-less protoplast L-form. J Gen Microbiol 139, 2715-2722.
Tuomanen, E., Lindquist, S., Sande, S., Galleni, M., Light, K., Gage, D. \& Normark, S. (1991). Coordinate regulation of betalactamase induction and peptidoglycan composition by the amp operon. Science 251, 201-204.

Vieira, J. \& Messing, J. (1982). The pUC plasmids, an M13mp7derived system for insertion mutagenesis and sequencing with synthetic universal primers. Gene 19, 259-268.

Wu, T. T. (1966). A model for three-point analysis of random general transduction. Genetics 54, 405-410.

Received 26 September 1994; revised 30 December 1994; accepted 9 January 1995. 